\title{
Social Media Usage versus Folklore to Tell Moral Value for Young Generation
}

\author{
A D Anggraeni ${ }^{1}$, H J Pentury ${ }^{2}$, A Nurfarkhana ${ }^{3}$, and D Pratama ${ }^{4}$ \\ Universitas Indraprasta PGRI, Jakarta Selatan, Indonesia ${ }^{1,2,3,4}$ \\ helda.jolanda@unindra.ac.id $\left.{ }^{2}\right\}$
}

\begin{abstract}
Social media touch the ethic folklore as a pedagogical tool to deliver the moral value messages to young generation is an inspiring issue to study. This study aims to analyze the contrast between the traditional folklore versus modern media social as pedagogical and communication tools using for a young generation. Folklore, an amazing traditional tool to teach and deliver moral messages to the young generation is changeable by a creative modern communication tool, social media. Drawing on deep experiences and expertise, we compare both media by study the literature to analyze the contrast between them. The method that is used in this study is a qualitative descriptive. The descriptions to show the contrast between using folklore and social media, and also implied the significant current trend between folklore touch and social media touch for the young generation. The result also shows that social media, finding resources and folklore were creative ways to deliver the messages for the young generation. As a pedagogical and communication tools, both social media and folklore allowed multiple literacies. The contrast between them expressed the ideas that both the tools of social media and folklore can create and encourage collaborative learning and mutual support to deliver moral value for the young generation.
\end{abstract}

Keywords: Folklore, Social Media, Moral Values

\section{Introduction}

Folklore is a narrative story, which can be categorized as an oral tradition. Folklore has a storyline that is clear and direct, namely: the first part includes characterizations and background, the content area developed problems and continues to climax, and the final section contains troubleshooting. Folklore is generally formed by a sequence of episodes that do not vary, but each has a unique character that is magical in very deep at every event [1].

Folklore is a special case of the ethnography- of speaking approach and makes an important contribution because it can direct attention to essential features of language that are now neglected or misconceived in linguistic theory [2]. Ben Botkin has defined the folklore as an item created by a community in the past, and it has become an identity for them, and this tradition has been passed down from generation to generation [3].

On the contrary, In the past, folklores are used as a tool of the pedagogical way of parents, teachers, educators and the scholars, the priests, notable people in society to express their messages for generations within Indonesian culture. The tales started as an oral tradition; 
being told by the parents in family, teachers, storyteller to the young generations. The folklore were often told, sung, or chanted in oral traditions such as stories, pantun, Fabel or children chants. Bartens asserts that moral values are the basic standard of good and evil which governs or rules individual behaviors and choices. This view obviously indicates that moral value, in everyday life, concerns with a set of principle which is applied to evaluate right versus wrong. In literary works, moral value is seen as a lesson which might inspire the readers to be positive or to live a better life [4].

All these ways used to teach the young generations about moral value. In our education system, the folklore belongs to Bahasa Indonesia subject, also taught in families culture, some society communities. It's in Indonesia literature; it's used to teach manners, and not as a communication tool. Folklores described as Indonesian traditional art, literature, knowledge, and practices that are passed in our society through oral communication and as an example. The tales tell the simple stories, simple messages, and simple lessons that are shown in our daily lives.

Social media literally influenced the young generation life. Social media takes over almost all young generation's education, passion, attitude even their lifestyle. Spoiled in instant and available high-tech design, young generation began to adopt, adapt and change their life and has since steadily made their image of life as 'Millenial Generation.' Some of them, especially young generation-teenagers and children in big cities, for example, has a habit of surfing on the internet either for doing school stuff or for having pleasure or hobbies and making money as well. "You can do it at any time and anywhere. This means it is more efficient in terms of time and free charge", they said.

In recent years media social has increasingly become renowned as an effective way of enhancing people engagement. The idea of communication is becoming new and changing. The ideas of informing the notion of multiliteracies are improving the complexity and interrelationship of different modes of meaning. Some different meaning modes are in the texts on literacy. The transformation of the text allowed by digital technology means the young generation use their own mobile phones in daily communication to express their literacy skills. They are allowed and free to express their thought, feeling, deeds and words on media social.

Social media as a global trend of the pedagogical tool will change any differently to the young generation, as we see lots of young generation love to express as well as explore their attitude and get the value most by using social media more than using folklore as a traditional simple way to communicate nowadays. Most of young generation influenced and picked up social media as a trendy communication tool than influenced by local communication, as an ethical folklore. This different pedagogical tools to deliver moral value for young generation inspire us to study more about the contrast between both of them. The trend now is breaking the barrier between 'ethnic' and 'modernn.' Something can be both.

\section{Method}

The method used in this study is qualitative descriptive. The findings are found in studying literature. The data is analyzed by using comparing and contrasting both social media and folklore. Break the material, both social media and folklore into parts, determining how the parts interrelate to one another or to an overall structure or purpose. The process is started by identifying the motives or causes, making inferences and finding evidence to support generalization of both folklore and social media. Compare and contrast, then categorized the results. 


\section{Result and discussion}

Currently, the new perspective shown for all parents, teachers, adult citizens, governments to have the necessary ways to integrate both technology and folklore as a pedagogical tool and media to deliver the words, the messages of moral value. Recognizing the characteristics of young generations needs, passions, technology available, surroundings, all together are things that are changing our pedagogical perspective to teach young generations about moral value and make it as a lifestyle.

Using folklore in media society as a social media available, can experimentally and learning in hands-on, low-risk online environment as a good example. Young generations participated in learning folklores using media social as their project-based learning in school or at home can support the real moral value with creative supportive guidance in a collaborative style.

Apart from the mystical elements that are in it, folklore has values and norms that are very relevant to collectively support the lives of the people, and become a filter for the negative effects of the advancement of science and technology or the era of globalization. These values and norms are characteristic of community groups, regulating behavior and relationships between individuals in the group. Values and norms are then developed into the customs of a supporting community group. Customary habits are not immersive in reflecting the orthodoxy or backwardness of a community group. In the life of today's modern society, these customs can actually become the basic capital in collective life. The values of local wisdom of a community can provide balance and order (harmony) of life, preserve nature or the environment, and others. Her inheritance to the next generation is also very useful in order to minimize the cultural gap in the younger generation.

Folk stories are very popular with the community because they can be used as role models, consolation, and are humorous. In addition, folklore also contains teachings of character or moral education and entertainment for the community. Every society has its own culture and values (local wisdom) in Indonesia. These values can be traced from folklore. Through folklore, local values are passed down from generation to generation through oral tradition or culture said. A variety of typical regional folklore which lives among the people conveys moral messages in a community. Call it the story "Malin Kundang" from West Sumatra, "Kasarung monkey" from West Java, "Cucumber Gold" from Central Java, "Crying Stone" of West Kalimantan, "Rara Jonggrang" from Yogyakarta. In each of these stories contained the values of local wisdom that can be used as a means to deliver people to the noble and dignified life. The moral values lie in the local wisdom are the core moral values of a nation; therefore by reading the folklore of a nation, we also learn the moral values [1].

Since Kant, moral is often used in yet another sense to refer to what is either categorically good (obligatory) or bad (forbidden) without reference to human desires [5].

When technology takes over, children are remain guided by their parents but not with the means of stories since televisions, smartphones, and tablets take over that role. Those gadgets provide attractive audiovisual to keep children busy. Actually, it is not completely bad since the programs still contain educational and moral lessons. However, as they grow up and become more adept at technology, they will be more exposed to the internet. In this global era, to value young generation using traditional stories, like folklores is the biggest challenge compare with social media. Making folklore as a tool to communicate the value as a trend is far from the good purpose. The popular social media is globally trending in all ages to share 
the words, messages or others. Technology creates creative media as a communication tool, pedagogical media, even as a marketing purpose.

Since social media provides an easy way to receive feedback and communicate with peers, young adults attitudes of themselves can be affected by using social media networks[6]. Social media has become part of our lives over the last decade. The advent of the Internet and social media has revolutionized how people communicate and access information daily. This revolution has impacted not only the life of the individual but also families and children. A recent publication in the UK by Fursland highlights the opportunities available from the Internet and social media for children and young people in care, which includes the development of friendships, gaining support, being part of a community and staying in touch with birth parents and other relatives. In the same publication, she also identified a series of challenges that mainly concern themselves with the vulnerabilities of children and adolescents in care and their supposed lack of skills to communicate and behave appropriately online [7].

Social media according to Kaplan and Haenlein is a group of Internet-based applications, built by ideology and Web 2.0 technology, while also enabling the creation and exchange of easily generalized content [8]. In simple terms, social media can be defined as online media that supports social interaction, and social media has used web-based technology that transforms communication into an interactive dialogue.

\begin{tabular}{|c|c|c|}
\hline Findings & Social Media & Folklore \\
\hline Communication tool & A main tool and media & $\begin{array}{l}\text { Only as a part of the media } \\
\text { of literature }\end{array}$ \\
\hline Creative media & $\begin{array}{l}\text { Global media, education, } \\
\text { business, Health, literacy, etc }\end{array}$ & Creative literacy in literature \\
\hline People's Character & $\begin{array}{l}\text { People's character change } \\
\text { into active and proactive }\end{array}$ & People's are passive \\
\hline Pedagogical method & $\begin{array}{l}\text { The modern method of } \\
\text { teaching }\end{array}$ & $\begin{array}{l}\text { Conventional teaching } \\
\text { method, using only } \\
\text { storytelling }\end{array}$ \\
\hline Ways of deliver messages & $\begin{array}{l}\text { Various ways to deliver } \\
\text { messages }\end{array}$ & Just tell the stories \\
\hline Relationship/interaction & Online interaction & Offline interaction \\
\hline Literacy process & Digital literacy & $\begin{array}{l}\text { Traditional literacy (using } \\
\text { printed media and oral) }\end{array}$ \\
\hline The News/Content & To the point tend to Hoax & The moral value \\
\hline The Message & All kind of messages & Moral message \\
\hline Fresh news & Up to date storyteller & traditional storyteller \\
\hline Creativity & High creativity & Simple creativity \\
\hline Language in use & Various languages & Indonesian and local \\
\hline Social life & Self share moment & Share the moment together \\
\hline Culture in use & Modern & Traditional \\
\hline Art & Digital & traditional \\
\hline Media & Digital & Printed media \\
\hline Speaking/telling story style & Out spoken & Metaphor spoken \\
\hline Attitude for the value & Open-minded, exposed & Positive straight-minded \\
\hline
\end{tabular}




\section{overexposed}

Table 1. Social Media versus Folklore

The sophistication of information technology, which is characterized by the wider use of social media, has facilitated statements of one's feelings, thoughts and opinions.

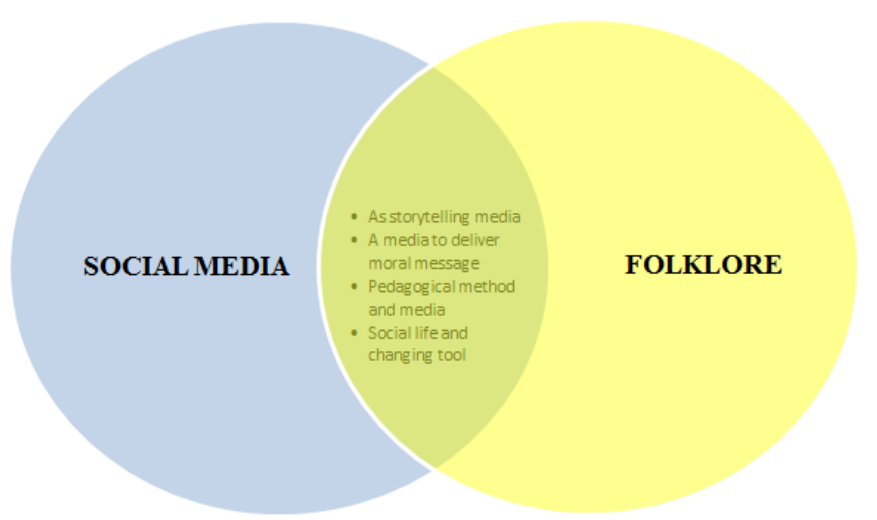

Figure 1. The Point of view from Social Media and Folklore

Folklore and social media can be used to convey moral messages to the younger generation. Folklore and social media can be used as storytelling media, a media to deliver moral message, pedagogical method and media and social life and changing tool.

Folklore are very effective media to instill various values and ethics towards children. Including causing feelings of empathy and sympathy for children. The values that can be learned from folklore the values of honesty, humility, solidarity, hard work, and so on. For elementary school students, it turns out storytelling is still always awaited. Story or folklore is one of the communication media to convey some lessons or moral messages to children. Apart from that, of course, other learning methods that are currently using sophisticated technology that are interesting for students. Conveying moral messages can be easily conveyed to children through a folklore.

\section{References}

[1] H. U. Kaltsum and R. D. Utami, "Folklores as English Teaching Media for The Young Learners," in International Conference on Science, Technology and Humanity, 2015.

[2] B. Morgan-Fleming, "Teaching as Performance: Connections between Folklore and Education," Curric. Inq., vol. 29, no. 3, pp. 273-291, Jan. 1999.

[3] S. H. Zaini, S. Z. Mokhtar, and M. Nawawi, "The Effect of Graphic Organizer on Students' Learning in School," Malaysian J. Educ. Technol., vol. 10, no. 1, p. 7, 2010.

[4] M. Abrar, "Learning from Fables: Moral Values in Three Selected English Stories," Din. Ilmu, vol. 16, no. 1, p. 47, Jun. 2016.

[5] D. Vokey, "Macintyre, moral value, and Mahayana Buddhism: Embracing the unthinkable in moral education," Educ. Theory, vol. 49, no. 1, pp. 91-106, Mar. 1999.

[6] M. Sponcil and P. Gitimu, "Use of social media by college students: Relationship to communication and self-concept," J. Technol. Res., vol. 4, pp. 1-13, 2013. 
[7] J. E. Simpson, "A divergence of opinion: how those involved in child and family social work are responding to the challenges of the Internet and social media: A divergence of opinion," Child Fam. Soc. Work, vol. 21, no. 1, pp. 94-102, Feb. 2016.

[8] P. W. Widyaningrum, "Peran Media Sosial sebagai Strategi Pemasaran pada Sewa Kostum Meiyu Aiko Malang," Al Tijarah, vol. 2, no. 2, p. 230, Dec. 2016. 